
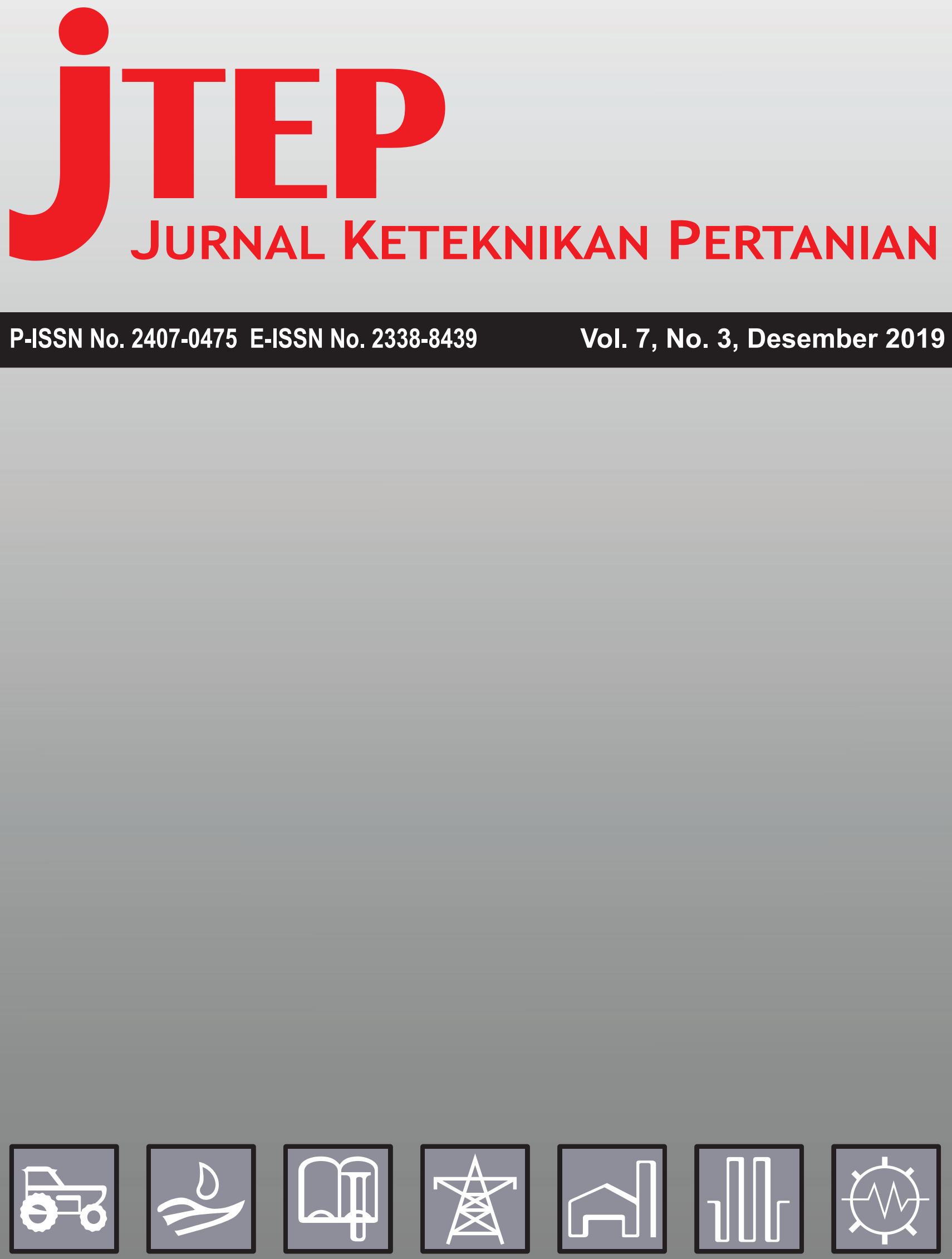

Publikasi Resmi
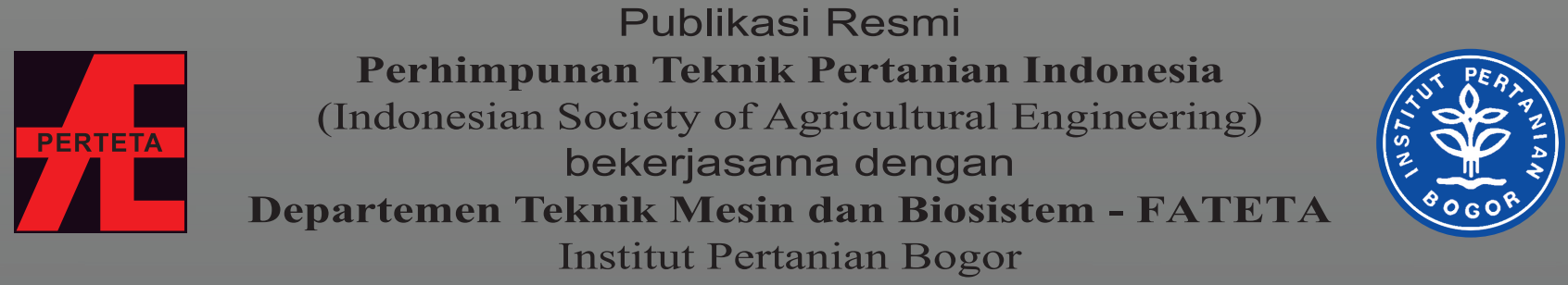


\section{jteP JURnal Keteknikan PERTANIAN}

Vol. 7, No. 3. Desember 2019

Jurnal Keteknikan Pertanian (JTEP) terakreditasi berdasarkan SK Dirjen Penguatan Riset dan Pengembangan Kementerian Ristek Dikti Nomor I/E/KPT/2015 tanggal 21 September 2015. Selain itu, JTEP juga telah terdaftar pada Crossref dan telah memiliki Digital Object Identifier (DOI) dan telah terindeks pada ISJD, IPI, Google Scholar dan DOAJ. JTEP terbit tiga kali setahun yaitu bulan April, Agustus dan Desember, Jurnal berkala ilmiah ini berkiprah dalam pengembangan ilmu keteknikan untuk pertanian tropika dan lingkungan hayati. Penulis makalah tidak dibatasi pada anggota PERTETA tetapi terbuka bagi masyarakat umum. Lingkup makalah, antara lain meliputi teknik sumberdaya lahan dan air, alat dan mesin budidaya pertanian, lingkungan dan bangunan pertanian, energi alternatif dan elektrifikasi, ergonomika dan elektronika pertanian, teknik pengolahan pangan dan hasil pertanian, manajemen dan sistem informasi pertanian. Makalah dikelompokkan dalam invited paper yang menyajikan isu aktual nasional dan internasional, review perkembangan penelitian, atau penerapan ilmu dan teknologi, technical paper hasil penelitian, penerapan, atau diseminasi, serta research methodology berkaitan pengembangan modul, metode, prosedur, program aplikasi, dan lain sebagainya. Penulisan naskah harus mengikuti panduan penulisan seperti tercantum pada website dan naskah dikirim secara elektronik (online submission) melalui http://journal.ipb.ac.id/index.php/jtep.

\section{Penanggungjawab:}

Ketua Departemen Teknik Mesin dan Biosistem, Fakultas Teknologi Pertanian,IPB

Ketua Perhimpunan Teknik Pertanian Indonesia

\section{Dewan Redaksi:}

Ketua : Yohanes Aris Purwanto (Scopus ID: 6506369700, IPB University)

Anggota : Abdul Hamid Adom (Scopus ID: 6506600412, University Malaysia Perlis)

(editorial Addy Wahyudie (Scopus ID: 35306119500, United Arab Emirates University)

board) Budi Indra Setiawan (Scopus ID: 55574122266, IPB University)

Balasuriya M.S. Jinendra (Scopus ID: 30467710700 , University of Ruhuna)

Bambang Purwantana (Scopus ID: 6506901423, Universitas Gadjah Mada)

Bambang Susilo (Scopus ID: 54418036400, Universitas Brawijaya)

Daniel Saputera (Scopus ID: 6507392012, Universitas Sriwjaya)

Han Shuqing (Scopus ID: 55039915600, China Agricultural University)

Hiroshi Shimizu (Scopus ID: 7404366016, Kyoto University)

I Made Anom Sutrisna Wijaya (Scopus ID: 56530783200, Universitas Udayana)

Agus Arif Munawar (Scopus ID: 56515099300, Universitas Syahkuala)

Armansyah H. Tambunan (Scopus ID: 57196349366, IPB University)

Kudang Boro Seminar (Scopus ID: 54897890200, IPB University)

M. Rahman (Scopus ID: 7404134933, Bangladesh Agricultural University)

Machmud Achmad (Scopus ID: 57191342583, Universitas Hasanuddin)

Muhammad Makky (Scopus ID: 55630259900, Universitas Andalas)

Muhammad Yulianto (Scopus ID: 54407688300, IPB University \& Waseda University)

Nanik Purwanti (Scopus ID: 23101232200, IPB University \& Teagasc Food Research Center Irlandia)

Pastor P. Garcia (Scopus ID: 57188872339 , Visayas State University)

Rosnah Shamsudin (Scopus ID: 6507783529, Universitas Putra Malaysia)

Salengke (Scopus ID: 6507093353, Universitas Hasanuddin)

Sate Sampattagul (Scopus ID: 7801640861, Chiang Mai University)

Subramaniam Sathivel (Scopus ID: 6602242315, Louisiana State University)

Shinichiro Kuroki (Scopus ID: 57052393500 , Kobe University)

Siswoyo Soekarno (Scopus ID: 57200222075 , Universitas Jember)

Tetsuya Araki (Scopus ID: 55628028600, The University of Tokyo)

Tusan Park (Scopus ID: 57202780408, Kyungpook National University) 


\section{Redaksi Pelaksana:}

Ketua : Usman Ahmad (Scopus ID: 55947981500, IPB University)

Sekretaris : Lenny Saulia (Scopus ID: 16744818700, IPB University)

Bendahara : Dyah Wulandani (Scopus ID: 1883926600, IPB University)

Anggota : Satyanto Krido Saptomo (Scopus ID: 6507219391, IPB University)

Slamet Widodo (Scopus ID: 22636442900, IPB University)

Liyantono (Scopus ID: 54906200300, IPB University)

Leopold Oscar Nelwan (Scopus ID: 56088768900, IPB University)

I Wayan Astika (Scopus ID: 43461110500, IPB University)

Agus Ghautsun Niam (Scopus ID: 57205687481, IPB University)

Administrasi : Diana Nursolehat (IPB University)

Penerbit: Perhimpunan Teknik Pertanian Indonesia (PERTETA) bekerjasama dengan Departemen Teknik Mesin dan Biosistem, Institut Pertanian Bogor.

Alamat: Jurnal Keteknikan Pertanian, Departemen Teknik Mesin dan Biosistem, Fakultas Teknologi Pertanian, Kampus Institut Pertanian Bogor, Bogor 16680.

Telp. 0251-8624 503, Fax 0251-8623 026,

E-mail: jtep@ipb.ac.id atau jurnaltep@yahoo.com

Website: web.ipb.ac.id/ jtep atau http://journal.ipb.ac.id/index.php/jtep

Rekening: BRI, KCP-IPB, No.0595-01-003461-50-9 a/n: Jurnal Keteknikan Pertanian

Percetakan: PT. Binakerta Makmur Saputra, Jakarta 


\section{Ucapan Terima Kasih}

Redaksi Jurnal Keteknikan Pertanian mengucapkan terima kasih kepada para Mitra Bebestari yang telah menelaah (me-review) Naskah pada penerbitan Vol. 7 No. 3 Desember 2019. Ucapan terima kasih disampaikan kepada: Prof.Dr.Ir. Bambang Purwantana, M.Agr (Fakultas Teknologi Pertanian, Universitas Gadjah Mada), Dr.Ir. Nugroho Tri Waskito, MP (Fakultas Pertanian dan Peternakan, Universitas Muhammadiyah Malang), Dr. Ardiansyah, S.TP, M.Si (Fakultas Pertanian, Universitas Jenderal Soedirman), Dr. Ridwan Rahmat (Balai Penelitian Pasca Panen Cimanggu), Prof.Dr.Ir. Budi Indra Setiawan, M.Agr. (Departemen Teknik Sipil dan Lingkungan, Fakultas Teknologi Pertanian, Institut Pertanian Bogor), Prof.Dr.Ir. Sutrisno M.Agr (Departemen Teknik Mesin dan Biosistem, Fakultas Teknologi Pertanian, Institut Pertanian Bogor), Dr.Ir. Wawan Hermawan, MS (Departemen Teknik Mesin dan Biosistem, Fakultas Teknologi Pertanian, Institut Pertanian Bogor), Dr.Ir. Dyah Wulandani, MSi (Departemen Teknik Mesin dan Biosistem, Fakultas Teknologi Pertanian, Institut Pertanian Bogor), Dr. Slamet Widodo, S.TP, M.Sc (Departemen Teknik Mesin dan Biosistem, Fakultas Teknologi Pertanian, Institut Pertanian Bogor), Dr. Liyantono, S.TP, M.Agr (Departemen Teknik Mesin dan Biosistem, Fakultas Teknologi Pertanian, Institut Pertanian Bogor) 


\title{
Identifikasi Ganoderma pada Tanaman Kelapa Sawit Berbasis Citra Multispektral
}

\author{
Ganoderma Identification on Oil Palm Tree Based on Multispectral Images \\ Mohamad Solahudin, Departemen Teknik Mesin dan Biosistem, Institut Pertanian Bogor. \\ Email: msoul9@yahoo.com \\ Fenry Winna Mutawally, Departemen Teknik Mesin dan Biosistem, Institut Pertanian Bogor. \\ Email: fenryw@gmail.com
}

\begin{abstract}
Basal Stem Rot (BSR) is a fatal disease caused by the fungus Ganoderma boninense. Currently in Indonesia the identification of oil palm plants suffering from BSR is done by directly observing oil palm plants one by one and pressing the palm tree trunks. However the direct checking method is felt to be less effective and efficient, its need another better method for detecting BSR. This study aims to evaluate the Ganoderma attack by using a multispectral camera, applying a neural network method to analyze Normalized Difference Vegetation index (NDVI) images, and analyzing the effect of altitude on the accuracy of multispectral camera performance. In this study, spectral data of oil palm trees were taken through the air at an altitude of $50 \mathrm{~m}, 60 \mathrm{~m}$, and $70 \mathrm{~m}$ with a multispectral camera mounted on a Unmanned Aerial Vehicle (UAV), then the spectral data were analyzed using artificial neural networks to identify oil palm plants that were attacked by Ganoderma and healthy plants. The results of this study conclude that multispectral cameras can identify oil palm plants that have been attacked by Ganoderma at an altitude of $50 \mathrm{~m}$ and 60 $m$ with utilization of artificial neural networks.
\end{abstract}

Keywords: Ganoderma, basal stem rot, multispectral camera, UAV, oil palm plantations

\begin{abstract}
Abstrak
Basal Stem Rot (BSR) adalah penyakit fatal yang disebabkan oleh jamur Ganoderma boninense. Saat ini di Indonesia identifikasi pohon kelapa sawit yang menderita BSR dilakukan dengan pengamatan secara langsung pohon kelapa sawit satu per satu dan menekan batang pohon kelapa sawit tersebut. Metode pengecekan secara langsung dirasakan kurang efektif dan efisien, sehingga diperlukan metode lain yang lebih baik untuk mendeteksi BSR. Penelitian ini bertujuan mengevaluasi serangan Ganoderma dengan menggunakan kamera multispektral, menerapkan metode jaringan syaraf tiruan untuk menganalisa citra Normalized Difference Vegetation index (NDVI), dan menganalisis pengaruh ketinggian terhadap akurasi kinerja kamera multispektral. Pada penelitian ini, data spektral tanaman kelapa sawit diambil melalui udara pada ketinggian $50 \mathrm{~m}, 60 \mathrm{~m}$, dan $70 \mathrm{~m}$ dengan kamera multispektral yang dipasang pada Unmanned Aerial Vehicle (UAV), kemudian data spektral tersebut dianalisa menggunakan jaringan syaraf tiruan untuk mengidentifikasi tanaman kelapa sawit yang terserang Ganoderma dan tanaman kelapa sawit yang sehat. Hasil pada penelitian ini menyimpulkan bahwa kamera multispektral dapat mengidentifikasi tanaman kelapa sawit yang terserang Ganoderma pada ketinggian $50 \mathrm{~m}$ dan $60 \mathrm{~m}$ dengan bantuan jaringan syaraf tiruan.
\end{abstract}

Kata kunci : Ganoderma, basal stem rot, kamera multispektral, UAV, tanaman kelapa sawit 


\section{Pendahuluan}

Minyak kelapa sawit merupakan salah satu komoditas unggulan yang paling banyak diekspor oleh Indonesia. Berdasarkan data publikasi Badan Pusat Statistik tahun 2018, pada tahun 2017 kelapa sawit merupakan komoditas utama sektor nonmigas dengan angka US\$20,340.9 juta (BPS 2018). Oleh karena itu, kelapa sawit merupakan salah satu komoditas terpenting untuk Negara Indonesia. Namun seperti halnya komoditas pertanian pada umumnya, tanaman kelapa sawit juga rentan terhadap gangguan hama dan penyakit. Salah satu penyakit yang sering ditemui pada pohon kelapa sawit adalah penyakit Basal Stem Rot (BSR) atau busuk pangkal batang.

BSR adalah penyakit fatal yang disebabkan oleh jamur Ganoderma boninense. Penyakit ini memiliki dampak yang signifikan terhadap produksi kelapa sawit. Identifikasi penyakit ini sejak stadium awal berperan penting dalam pengelolaan penyakit kelapa sawit karena penyakit ini belum ditemukan obat dan cara perawatannya (Liaghat et al 2014). BSR sulit dideteksi karena perkembangannya yang sangat lambat dan tidak ditemukan perbedaan visual antara pohon kelapa sawit sehat dan yang terkena BSR. Pengidentifikasian mudah dilakukan pada pohon kelapa sawit dewasa atau saat jamur telah membentuk tubuh buah, akibatnya penyakit menjadi lebih sulit untuk dikendalikan (Susanto 2013). Pada stadium lanjut ini setengah dari jaringan pada batang pohon kelapa sawit telah mati (Paterson 2007). Saat ini di Indonesia identifikasi pohon kelapa sawit yang menderita BSR dilakukan dengan cara mengecek pohon kelapa sawit satu per satu dan menekan batang pohon kelapa sawit tersebut. Cara tersebut tidak efektif karena ahli penyakit harus menyusuri setiap pohon pada kebun kelapa sawit yang sangat luas.

Remote sensing adalah metode yang telah secara luas digunakan dan terbukti efektif dalam pengelolaan komoditas pertanian. Remote sensing adalah suatu perolehan informasi objek dalam skala kecilmaupun besar dengan cara merekam menggunakan alat penginderaan tanpa berhubungan langsung terhadap objek (Chipman et al. 2011). Remote sensing dapat dilakukan dari luar angkasa, udara, juga dari darat (Thomson, 2010). Salah satu pemanfaatan teknologi remote sensing yang sedang berkembang di Indonesia adalah pemanfaatan Unmanned Aerial Vechicle (UAV). Tetapi sejauh ini perusahaan perkebunan memanfaatkan UAV sebatas hanya untuk pemetaan lahan dengan kamera biasa. Berdasarkan Shafri (2011) pada penelitiannya yang berjudul "Spectral discrimination ofhealthy and Ganoderma-infected oil palms from hyperspectral data", pohon kelapa sawit yang terserang Ganoderma dapat diidentifikasi berdasarkan data spektralnya (Shafri, 2011). Jadi jika pemetaan lahan dengan drone dilakukan dengan menggunakan kamera multispektral, maka pengguna dapat mengidentifikasi pohon mana saja yang terserang Ganoderma.

Penelitian ini bertujuan untuk melakukan evaluasi serangan Ganoderma pada perkebunan kelapa sawit berbasis kamera multispektral. Metode analisis yang digunakan adalah metode analisis nilai NDVI, analisis nilai beberapa reflektasi gelombang multispektral, dan penggunaan jaringan syaraf tiruan pengenalan pola sebagai alat bantu analisis nilai reflektansi gelombang multispektral

Penelitian ini dibatasi pada penentuan teknis menggunakan kamera multispektral dan UAV untuk mengidentifikasi serangan Ganoderma pada tanaman kelapa sawit pada beberapa ketinggian pengambilan data $(50 \mathrm{~m}, 60 \mathrm{~m}$, dan $70 \mathrm{~m})$. Kondisi tanaman kelapa sawit hanya dibedakan menjadi dua kategori, yaitu tanaman kelapa sawit sehat dan tanaman kelapa sawit yang terserang Ganoderma, tanpa membedakan stadium BSR.

\section{Bahan dan Metode}

Penelitian dilakukan pada bulan Januari sampai Maret 2019. Lokasi penelitian adalah kebun percobaan kelapa sawit Cikabayan Atas Institut Pertanian Bogor (IPB) Dramaga, Kabupaten Bogor,
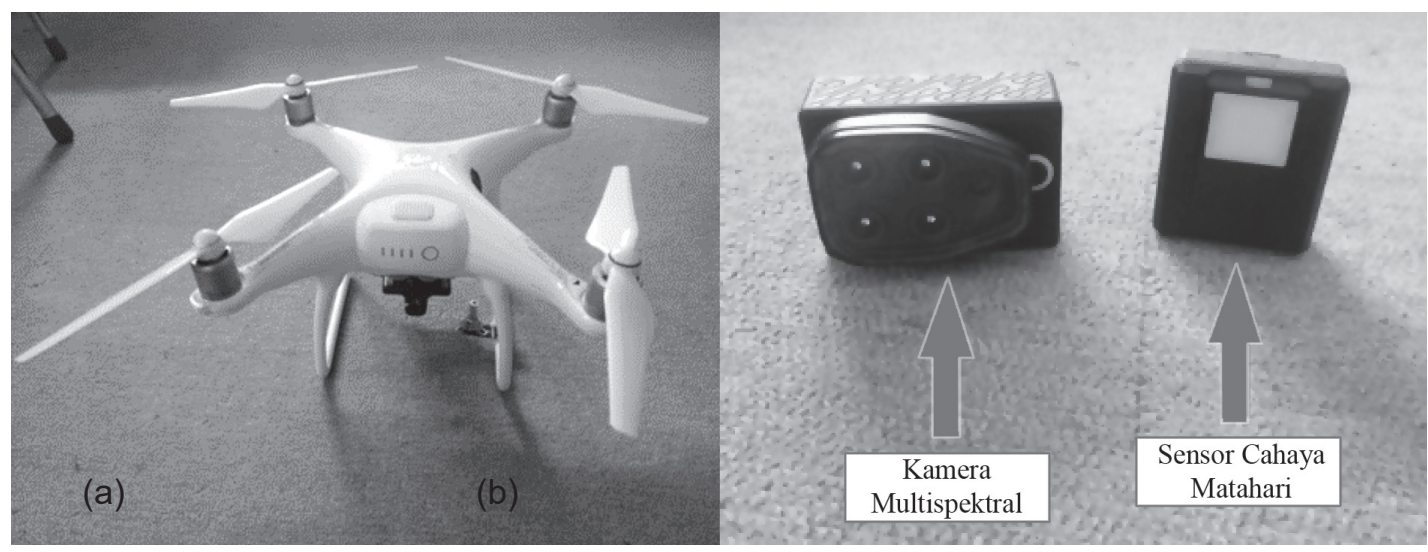

Gambar 1. Perangkat penangkap citra (a) UAV Phantom 4 (b) Kamera multispektral. 
Provinsi Jawa Barat. Lokasi penelitian terletak pada koordinat 6.5491003 LS, 106.7162521 BT.

Alat dan bahan yang digunakan pada penelitian ini adalah UAV Phantom DJI 4 yang dilengkapi dengan kamera multispektral Parrot Sequoia untuk menangkap citra perkebunan kelapa sawit. Citra hasil tangkapan diolah dengan bantuan beberapa perangkat lunak antara lain Pix4d Capture, Pix4d mapper, dan Matlab 7.8.

Proses pengambilan data diawali dengan membuat alur terbang UAV dengan software Pix4d Capture dan dilakukan dengan menggunakan UAV Phantom DJl 4 yang dipasang kamera multispektral Parrot Sequoia. Pengambilan data dilakukan pada pagi hari. Hal ini dilakukan karena kecepatan angin pada pagi hari masih cenderung rendah sehingga mengurangi risiko UAV goyang saat pemotretan yang menyebabkan buruknya kualitas gambar yang didapat. Pengambilan gambar yang optimum dilakukan pada pagi hari karena efek pantulan cahaya dari matahari masih lemah. (Kasih 2012)

Pengambilan data dilakukan pada ketinggian $50 \mathrm{~m}, 60 \mathrm{~m}$, dan.70 m. Data yang diperoleh dari pemotretan digabungkan menjadi satu peta multispektral orthomosaic dengan Pix4d Mapper. Parrot Sequoia memiliki sensor Near Infrared (NIR) dan red-edge sehingga peta multispektral orthomosaic tersebut dapat diolah menjadi peta Normalized Difference Vegetation Index (NDVI) dengan software Pix4d Mapper. Langkah selanjutnya dilakukan cropping pada tiap tanaman kelapa sawit dengan menggunakan fungsi imtool pada Matlab agar data spektral tanaman kelapa sawit dapat dianalisis satu per satu tanpa terganggu dengan data spektral jalan dan tanaman kelapa sawit yang lain. Kemudian nilai pantulan spektral dari tiap band diambil dengan fungsi multibandread.

Pada penelitian ini analisis nilai NDVI dilakukan dengan berbagai pendekatan yaitu dengan peta
NDVI dan komponen nilai NDVI tiap tanaman berdasarkan reflektansi spektrrum warna green, red, red edge, dan near infrared. Sebagian data tersebut dilengkapi dengan data hasil pengecekan kesehatan kelapa sawit secara langsung dilapangan kemudian dijadikan data input bagi training jaringan syaraf tiruan untuk mengidentifikasi antara tanaman kelapa sawit yang terserang Ganoderma dengan tanaman kelapa sawit yang sehat.

Proses pengambilan data pada penelitian ini dilakukan di Kebun Percobaan Kelapa Sawit Cikabayan Atas, dengan menggunakan sensor multispektral Parrot Sequoia yang diimplementasikan pada UAV Phantom 4. Pemilihan lokasi dilandasi oleh ditemukannya jamur Ganoderma pada beberapa tanaman kelapa sawit pada kebun percobaan kelapa sawit Cikabayan Atas. UAV diterbangkan dengan remotecontrol yang terhubung dengan aplikasi Pix4d Capture. Peta lokasi penelitian diakses melalui aplikasi Pix4d Capture lalu alur terbang dibuat dengan menggambarkan rute terbang UAV. Pada penelitian ini, diambil $500 \mathrm{~m}^{2}$ dari kebun percobaan kelapa sawit Cikabayan. Gambar rencana terbang dapat dilihat pada Gambar 2.

Berbeda halnya dengan misi penerbangan menggunakan UAV dengan kamera biasa yang menggunakan overlap dan sidelap untuk menentukan waktu pemotretan atau pengambilan gambar, saat menggunakan parrot sequoia parameter yang diatur untuk waktu pemotretan adalah interval waktu pengambilan gambar. Penentuan interval waktu pengambilan gambar dilakukan berdasarkan buku panduan parrot sequoia yang diatur berdasarkan kecepatan UAV dan ketinggian penerbangan UAV. Tabel hubungan kecepatan UAV, ketinggian UAV, dan interval waktu pemotretan dapat dilihat pada tabel 1 .

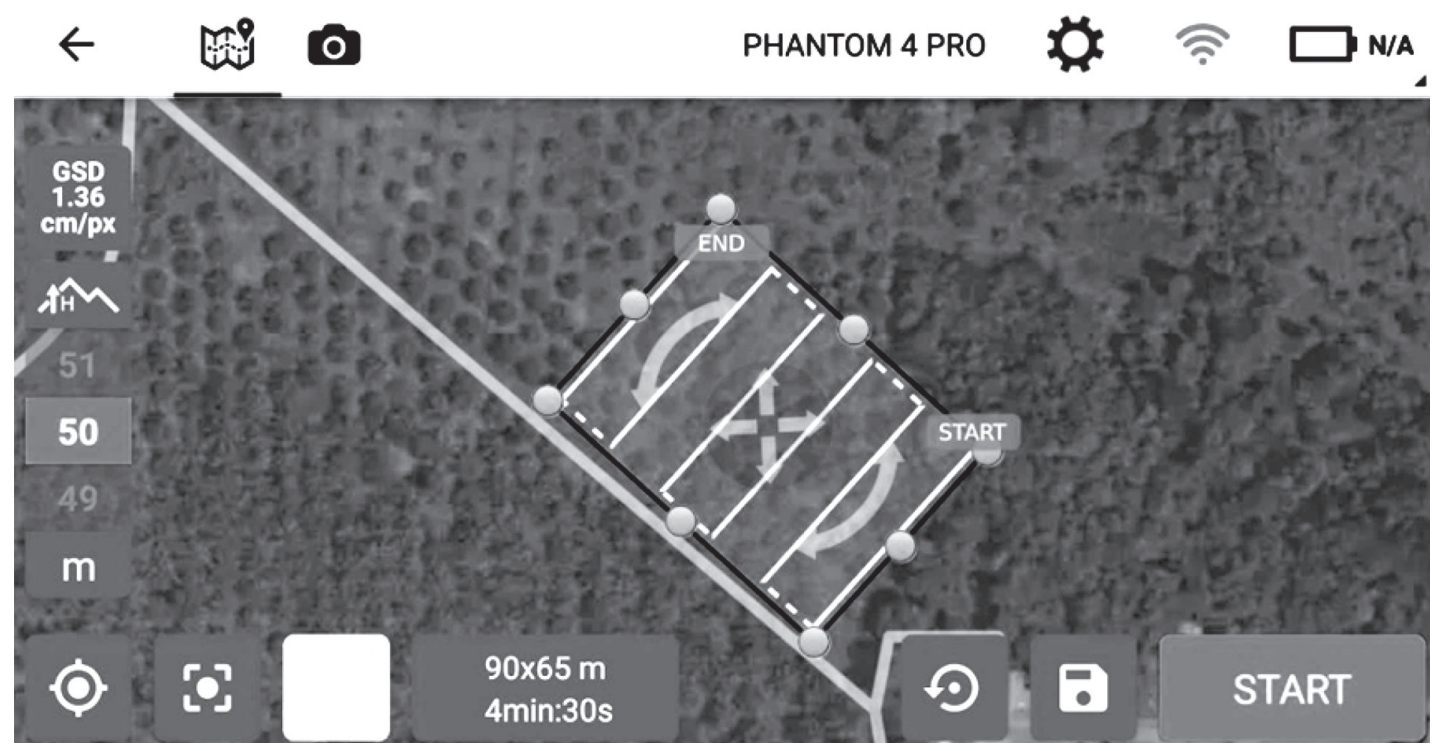

Gambar 2. Penentuan rute terbang. 


\section{Hasil dan Pembahasan}

\section{Pengambilan Data}

Penyebab penyakit BSR pada pohon kelapa sawit adalah jamur Ganoderma boninense. Ganoderma boninense adalah kelompok cendawan busuk putih, cendawan ini bersifat lignolitik. Oleh sebab itu, cendawan ini mempunyai aktivitas yang lebih tinggi dalam mendegradasi lignin dibandingkan kelompok lain. Komponen penyusun dinding sel tanaman adalah lignin, selulosa, dan hemiselulosa. Selulosa merupakan bagian terbesar yang terdapat dalam dinding sel tanaman, yaitu berkisar antara 39-55 persen, kemudian lignin 18-33 persen, dan hemiselulosa 21-24 persen (Martawijaya et al. 2005). BSR adalah penyakit yang paling sering dijumpai pada pohon kelapa sawit di Indonesia. Semakin hari, persentase BSR pada pohon kelapa sawit makin meningkat. Dulunya BSR dianggap sebagai penyakit kebun tua karena penyakit ini hanya dijumpai pada pohon kelapa sawit yang kebunnya sudah tua, sekarang

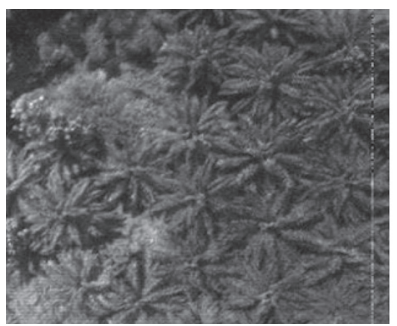

(a)

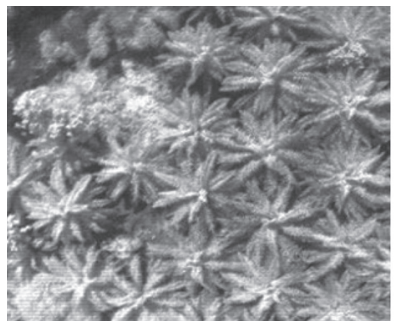

(c)

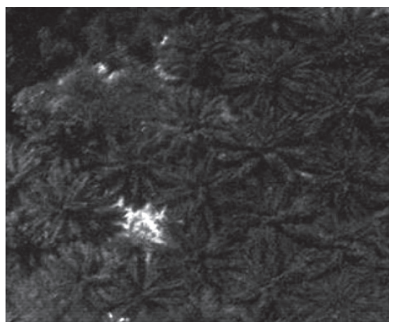

(b)

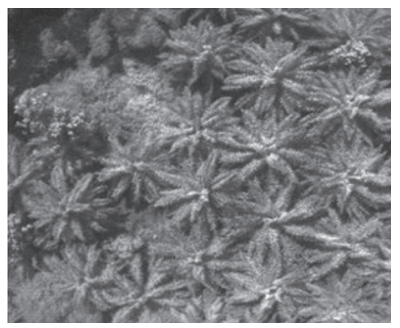

(d)
Gambar 3. Hasil gambar dari Parrot Sequoia pada spektrum

(a) green (b) red (c) red edge (d) near infra red.

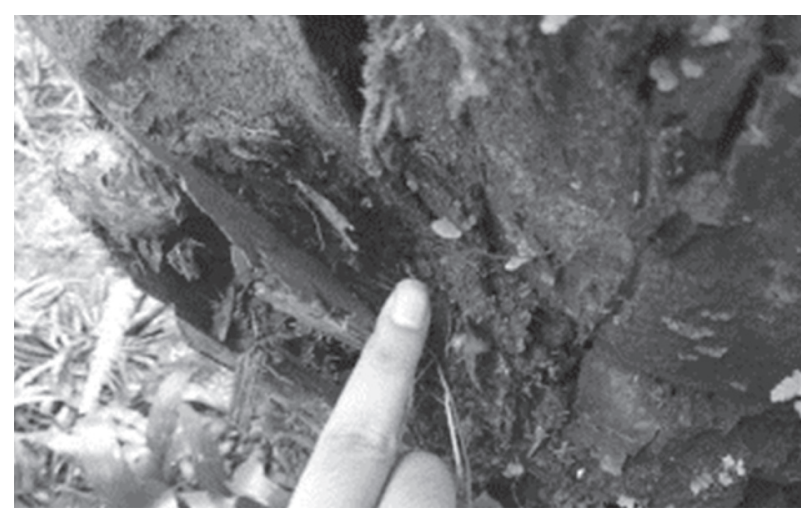

Gambar 4 Basidiokarp Ganoderma pada tanaman kelapa sawit.
Tabel 1. Penentuan interval pemotretan.

\begin{tabular}{ccccc}
\hline \multirow{2}{*}{$\begin{array}{c}\text { Ketinggian } \\
(\mathrm{m})\end{array}$} & \multicolumn{4}{c}{$\begin{array}{c}\text { Interval Waktu Pemotretan }(\mathrm{s}) \\
\text { pada Berbagai Kecepatan }\end{array}$} \\
\cline { 2 - 5 } & $5 \mathrm{~m} / \mathrm{s}$ & $10 \mathrm{~m} / \mathrm{s}$ & $13 \mathrm{~m} / \mathrm{s}$ & $20 \mathrm{~m} / \mathrm{s}$ \\
\hline 50 & 1.8 & 0.9 & 0.7 & 0.3 \\
60 & 2.2 & 1.1 & 0.8 & 0.4 \\
70 & 2.6 & 1.3 & 1.0 & 0.5 \\
\hline
\end{tabular}

Sumber : Parrot SA (2017)

penyakit ini terdapat juga di kebun yang masih muda (Semangun 2000). Analisis terhadap BSR dilakukan melalui pemotretan lahan kebun kelapa sawit dilakukan pada tiga ketinggian yaitu $50 \mathrm{~m}$, $60 \mathrm{~m}, 70 \mathrm{~m}$. Pembatasan ketinggian pengambilan gambar dilandasi oleh banyaknya noise yang akan mengganggu hasil pengambilan gambar dan sinyal yang ditangkap oleh kamera semakin kecil pada ketinggian yang terlalu tinggi. Data yang diperoleh dari pemotretan udara tersimpan pada memory card Parrot Sequoia berupa satu set gambar yang terdiri dari lima gambar berformat .tiff, yaitu gambar cahaya tampak, gambar green pada panjang gelombang $550 \mathrm{~nm}$, red pada panjang gelombang $660 \mathrm{~nm}$, red edge pada panjang gelombang $735 \mathrm{~nm}$, dan near infrared pada panjang gelombang 790. Titik pemotretan mencakup tanaman kelapa sawit yang terserang Ganoderma serta tanaman kelapa sawit yang sehat sebagai pembanding antara hasil yang didapat. Foto hasil pemotretan dengan Parrot Sequoia dapat dilihat pada Gambar 3.

Berdasarkan observasi di lapangan terhadap tanaman kelapa sawit yang terserang Ganoderma menyatakan bahwa stadium serangan Ganoderma yang ada pada kebun adalah stadium 3. Hal ini ditunjukkan dengan basidiokarp cendawan Ganoderma yang terdapat pada tanaman kelapa sawit. Umumnya basidiokarp berkembang sedikit di atas dan mengelilingi bagian pangkal batang yang sakit. Ukuran basidiokarp yang bertambah besar menunjukkan perkembangan penyakit semakin lanjut dan akhirnya menyebabkan kematian pada tanaman (Arifin et al. 2000). Basidiokarp Ganoderma pada tanaman kelapa sawit di kebun percobaan kelapa sawit Cikabayan dapat dilihat pada Gambar 4.

\section{Analisis Citra Multispektral}

Hasil olahan peta NDVI pada ketinggian $50 \mathrm{~m}$ dan $60 \mathrm{~m}$ dapat dilihat pada Gambar 5. Pada tersebut dapat dilihat perbedaan warna yang diberikan tanaman kelapa sawit dengan non tanaman kelapa sawit. Namun antara setiap tanaman kelapa sawit tidak ditemukan perbedaan yang dapat dijadikan parameter dasar untuk membedakan tanaman kelapa sawit yang terserang Ganoderma dengan tanaman kelapa sawit yang sehat. Oleh karena itu, metode dengan menggunakan peta NDVI tidak dapat diterapkan untuk mengidentifikasi 
Tabel 2 Data NDVI tiap tanaman pada ketinggian $50 \mathrm{~m}$ dan $60 \mathrm{~m}$.

\begin{tabular}{ccc}
\hline Pohon ke & $50 \mathrm{~m}$ & $60 \mathrm{~m}$ \\
\hline 1 & 0.5740 & 0.5726 \\
2 & 0.5372 & 0.5213 \\
3 & 0.5532 & 0.5809 \\
4 & 0.4687 & 0.4895 \\
5 & 0.4864 & 0.4548 \\
6 & 0.4731 & 0.4707 \\
7 & 0.5944 & 0.5277 \\
8 & 0.5644 & 0.5584 \\
9 & 0.5572 & 0.4879 \\
10 & 0.6072 & 0.5065 \\
11 & 0.5198 & 0.5509 \\
12 & 0.5836 & 0.5036 \\
\hline
\end{tabular}

Ganoderma pada tanaman kelapa sawit.

Pendekatan yang dilakukan selanjutnya adalah dengan menganalisa nilai pantulan spektral yang diberikan daun tanaman kelapa sawit. Untuk menganalisa nilai pantulan spektral daun setiap tanaman kelapa sawit, analisa dilakukan pada satu daerah pada kebun percobaan kelapa sawit Cikabayan yang mencakup tanaman kelapa sawit yang terserang Ganoderma dan tanaman kelapa sawit yang sehat. Sebanyak 12 tanaman kelapa sawit dipilih sebagai sampel untuk dianalisa. Daerah kebun percobaan kelapa sawit Cikabayan yang dipilih dapat dilihat pada Gambar 6 .

Pengolahan citra dilakukan per tanaman untuk mendapatkan nilai reflektansi spektral pada setiap panjang gelombang menggunakan software MatLab. Data reflektan setiap pixel pada satu tanaman dirata-ratakan untuk mendapatkan

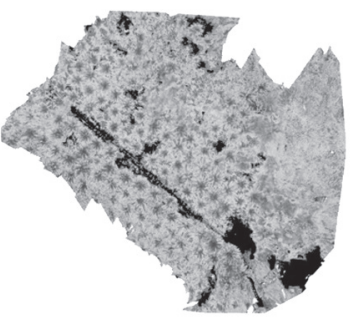

(a)

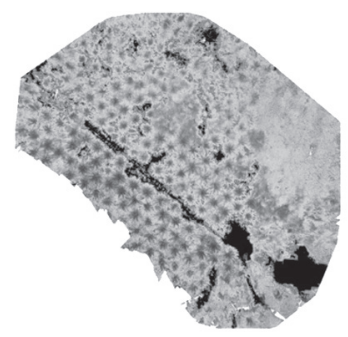

(b)
Gambar 5. Peta NDVI hasil pemotretan pada ketinggian (a) $50 \mathrm{~m}$ dan (b) $60 \mathrm{~m}$.

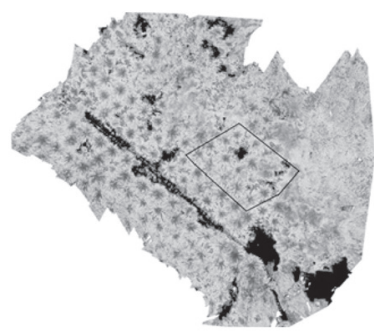

Gambar 6. Lokasi pengambilan contoh 12 pohon kelapa sawit. reflektansi spektral untuk masing masing panjang gelombang yang selanjutnya diplot dan dibandingkan dengan grafik yang diperoleh dari penelitian Liaghat S. (2014). Karena penelitian ini tidak menggunakan spectrophotometer, maka grafik hanya di plot berdasarkan empat titik pada empat panjang gelombang. Nilai reflektansi spektral dari panjang gelombang $550 \mathrm{~nm}$ sampai $660 \mathrm{~nm}$ selalu turun, lalu dari $660 \mathrm{~nm}$ sampai $735 \mathrm{~nm}$ selalu naik dengan perbedaan peningkatan yang cukup signifikan antar tanaman kelapa sawit. Dilanjutkan dengan penurunan pada panjang gelombang $790 \mathrm{~nm}$. Pola tersebut sama dengan grafik pada penelitian Liaghat, dan pada grafik dapat dilihat perbandingan antara reflektan dari setiap tanaman untuk membedakan tanaman yang sakit dan tanaman sehat. Grafik hasil plot data reflektan pada setiap panjang gelombang pada ketinggian $50 \mathrm{~m}$ dapat dilihat pada Gambar 7. Berdasarkan grafik tersebut dapat dilihat bahwa nilai reflektansi menunjukan bahwa pemotretan pada ketinggian 50 m mampu membedakan antara tanaman sehat dan tanaman yang sakit pada batas nilai reflektasi NIR $45 \%$, dimana tanaman sakit memiliki nilai reflektasi NIR kurang dari $45 \%$.

Seperti halnya pada ketinggian $50 \mathrm{~m}$, grafik reflektan pada ketinggian $60 \mathrm{~m}$ dapat secara jelas membedakan antara tanaman yang terkena Ganoderma dengan tanaman yang sehat meskipun pada range reflektansi yang berbeda. Pada ketinggian $70 \mathrm{~m}$, reflektansi spektral pada setiap pohon cenderung memiliki nilai yang hampir sama. Hal ini disebabkan karena jarak antara kamera dan obyek yang terlalu jauh, sehingga data yang diperoleh pada jarak tersebut tidak akurat dan tidak dapat digunakan. Oleh karena itu, pengambilan data pada ketinggian $70 \mathrm{~m}$ tidak dapat digunakan sebagai acuan sebagai metode pendeteksian serangan Ganoderma.

\section{Analisis nilai NDVI}

Berdasarkan hasil observasi lapangan bahwa pohon 4 dan 5 merupakan tanaman yang terserang Ganoderma dan data nilai NDVI setiap tanaman, nilai NDVI 0.49 dapat dijadikan sebagai acuan apakah tanaman kelapa sawit terserang cendawan

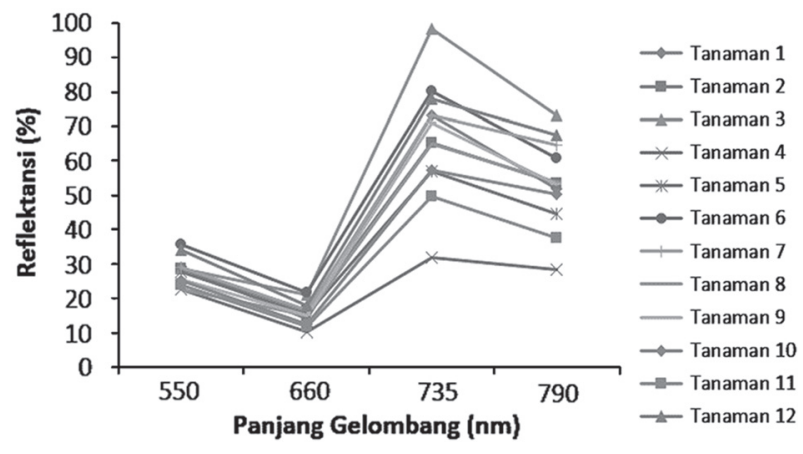

Gambar 7. Hubungan reflektansi dan panjang gelombang (ketinggian $50 \mathrm{~m}$ ). 
Ganoderma. Pada ketinggian $50 \mathrm{~m}$, tanaman yang dianggap terserang adalah pohon ke 4, pohon ke 5, dan pohon ke 6. Secara langsung, pada pohon ke 6 , tidak terlihat adanya tubuh buah cendawan Ganoderma di sekitar tanaman kelapa sawit tersebut. Tetapi seperti pada pembahasan sebelumnya, tanaman kelapa sawit tersebut mungkin sudah terserang tetapi perkembangan Ganoderma belum dapat dilihat oleh mata manusia, karena masih dalam stadium awal.

Pada data hasil pemotretan ketinggian $60 \mathrm{~m}$ menunjukkan hasil yang sama dengan ketinggian $50 \mathrm{~m}$ selain pada pohon ke 9. Pada hasil gambar dari ketinggian $60 \mathrm{~m}$, pohon ke 9 dianggap terserang Ganoderma sedangkan pada hasil gambar dari ketinggian $50 \mathrm{~m}$ dan pengamatan langsung, tanaman kelapa sawit tersebut dianggap sehat. Berdasarkan hasil analisis NDVI tersebut, maka akurasi yang diperoleh adalah $87.5 \%$. Hal ini disebabkan adanya kesalahan deteksi pada 3 data dari total 24 data.

\section{Analisis nilai NDVI dengan Jaringan Syaraf Tiruan}

Metode selanjutnya yang akan digunakan adalah dengan pendekatan menggunakan jaringan syaraf tiruan (JST). Jenis jaringan syaraf tiruan yang akan digunakan adalah jaringan syaraf tiruan pengenalan pola. Pada jaringan syaraf tiruan tipe pengenalan pola, jaringan akan mengklasifikasikan kumpulan masukan yang diberikan kepada jaringan ke dalam kategori target. Struktur model jaringan syaraf tiruan dapat dilihat pada Gambar 8.

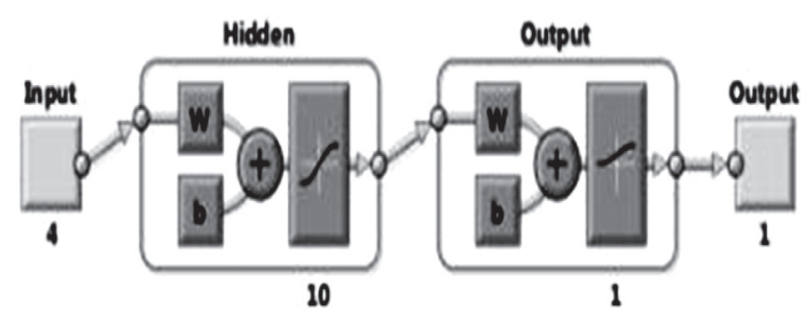

Gambar 8. Struktur model jaringan syaraf tiruan.

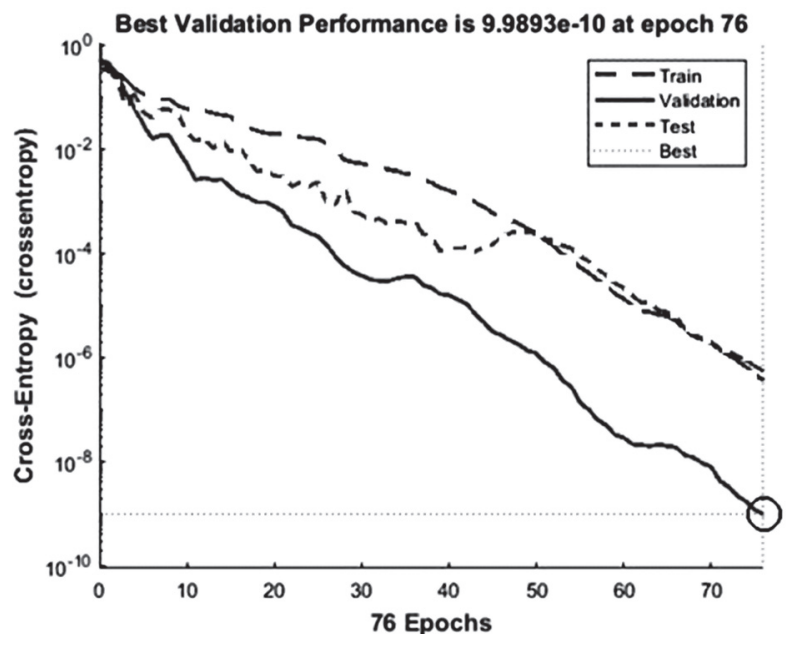

Tabel 3. Hasil keluaran.

\begin{tabular}{|c|c|c|c|}
\hline \multicolumn{2}{|r|}{$50 \mathrm{~m}$} & \multicolumn{2}{|c|}{$60 \mathrm{~m}$} \\
\hline Tanaman ke & Output & Tanaman ke & Output \\
\hline 1 & $1.4811 \times 10^{-08}$ & 1 & $1.2199 \times 10^{-12}$ \\
\hline 2 & $2.0007 \times 10^{-15}$ & 2 & $1.2840 \times 10^{-09}$ \\
\hline 3 & $1.9104 \times 10^{-16}$ & 3 & $1.3929 \times 10^{-12}$ \\
\hline 4 & 1.0000 & 4 & 1.0000 \\
\hline 5 & 1.0000 & 5 & 1.0000 \\
\hline 6 & $3.6891 \times 10^{-06}$ & 6 & $2.3524 \times 10^{-08}$ \\
\hline 7 & $7.3676 \times 10^{-18}$ & 7 & $5.5746 \times 10^{-09}$ \\
\hline 8 & $1.4715 \times 10^{-17}$ & 8 & $3.4934 \times 10^{-08}$ \\
\hline 9 & $1.2343 \times 10^{-15}$ & 9 & $1.5819 \times 10^{-06}$ \\
\hline 10 & $4.5659 \times 10^{-09}$ & 10 & $1.4303 \times 10^{-10}$ \\
\hline 11 & $2.7383 \times 10^{-06}$ & 11 & $1.3771 \times 10^{-16}$ \\
\hline 12 & $9.5901 \times 10^{-18}$ & 12 & $1.2404 \times 10^{-07}$ \\
\hline
\end{tabular}

Pada analisis dengan jaringan syaraf tiruan ini masukan berupa data reflektan spektral Green, Red, Red Edge, dan Near Infrared dari setiap tanaman kelapa sawit. Sedangkan data target berupa 1 dan 0 , dengan 1 adalah tanaman yang terserang Ganoderma dan 0 adalah tanaman yang sehat. Jaringan akan membagi seluruh data menjadi tiga bagian secara acak menjadi data latihan, data tes, dan data validasi. Hidden layer pada jaringan syaraf tiruan menggunakan fungsi aktivasi sigmoid untuk mendapatkan bobot dari setiap masukan. Jaringan akan terus melakukan pengulangan untuk mendapatkan bobot terbaik dengan galat terkecil. Percobaan dengan data pemotretan pada ketinggian $50 \mathrm{~m}$ dan $60 \mathrm{~m}$, jaringan menunjukkan hasil yang baik. Hasil performa jaringan dapat dilihat pada Gambar 9.

Pada percobaan melatih jaringan syaraf tiruan, JST melakukan pengulangan sebanyak 76 , dengan hasil yang optimal didapatkan pada pengulangan ke-76. Hasil keluaran dari jaringan berupa angka dari 0 sampai 1 . Jaringan membulatkan angka lebih kecil sama dengan 0.5 menjadi 0 dan lebih besar dari 0.5 menjadi 1 . Hasil keluaran jaringan dapat dilihat pada Tabel 3. Pemilihan data untuk ketiga bagian data tersebut dipilih secara acak oleh jaringan. Model jaringan syaraf tiruan yang digunakan berhasil mengklasifikasikan semua 24 data tersebut ke dalam kategori yang benar. Matriks klasifikasi jaringan dapat dilihat pada Gambar 10.

Tidak ada galat yang terjadi pada jaringan menunjukkan keberhasilan jaringan dalam mengklasifikasikan tanaman kelapa sawit antara yang terserang Ganoderma dengan tanaman kelapa sawit yang sehat berdasarkan data reflektansi spektral dan ketinggian. Sehingga metode terbaik untuk mengidentifikasi Ganoderma pada tanaman kelapa sawit adalah menggunakan pendekatan jaringan syaraf tiruan.

Gambar 9. Performansi jaringan syaraf tiruan. 
Validasi JST dilakukan dengan menggunakan 12 tanaman lain yang sehat sebagai input. Pemilihan 12 tanaman sebagai validasi dilakukan karena pada pembuatan alur terbang hanya menangkap 24 tanaman, sehingga tanaman yang citranya tertangkap jelas dan tidak termasuk ke dalam data pembuatan jaringan hanya 12 tanaman. Daerah tanaman yang digunakan sebagai data validasi dapat dilihat pada Gambar 11. Hasil output dari jaringan menunjukkan angka dibawah 0.5 yang berarti semua tanaman sehat. Hal ini menunjukkan bahwa jaringan mampu mengidentifikasikan tanaman lain pada kebun percobaan Cikabayan yang sehat sebagai sehat.

\section{Kesimpulan}

Penyakit BSR dan cendawan Ganoderma dapat diidentifikasi dengan menggunakan kamera multispektral Parrot Sequoia yang dipasang pada UAV. Hasil pengamatan citra NDVI tidak menunjukkan secara jelas perbedaan tanaman yang terserang Ganoderma dengan tanaman

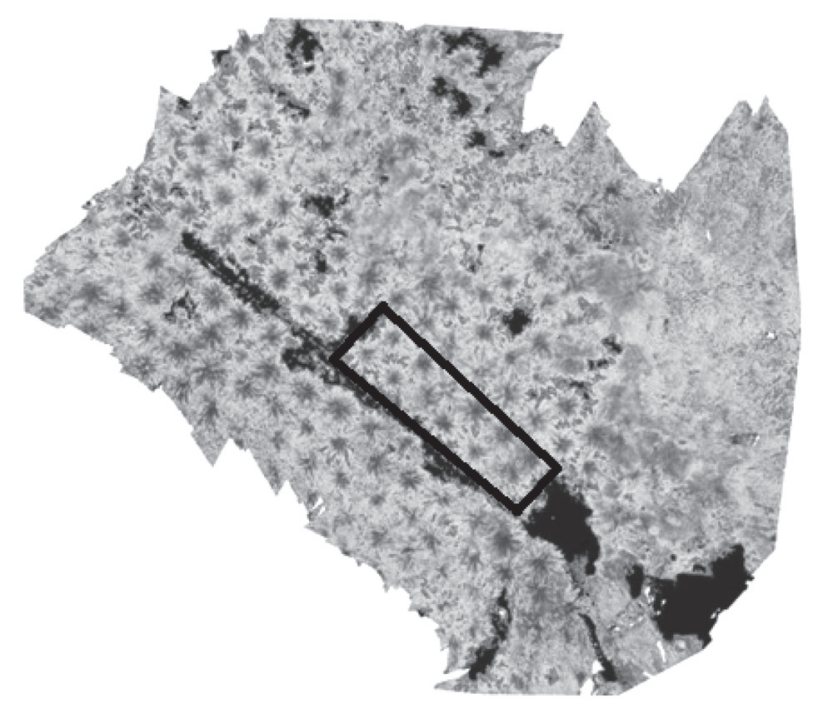

Gambar 11. Lokasi pengambilan data validasi.

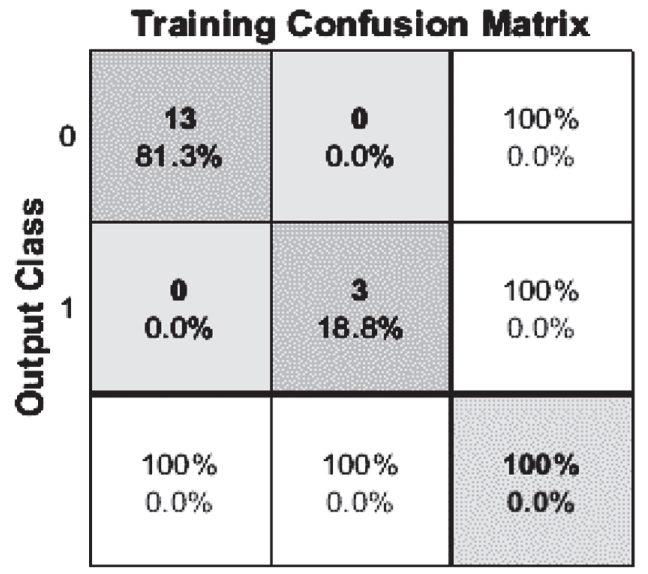

0

Target Class

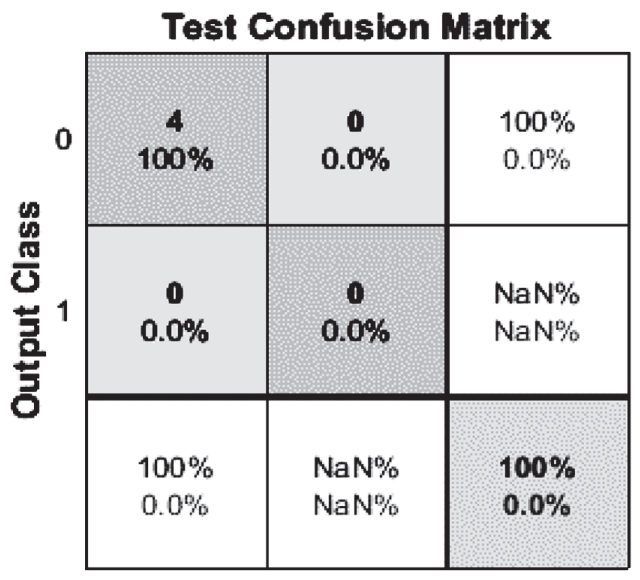

0 $\wedge$

Target Class

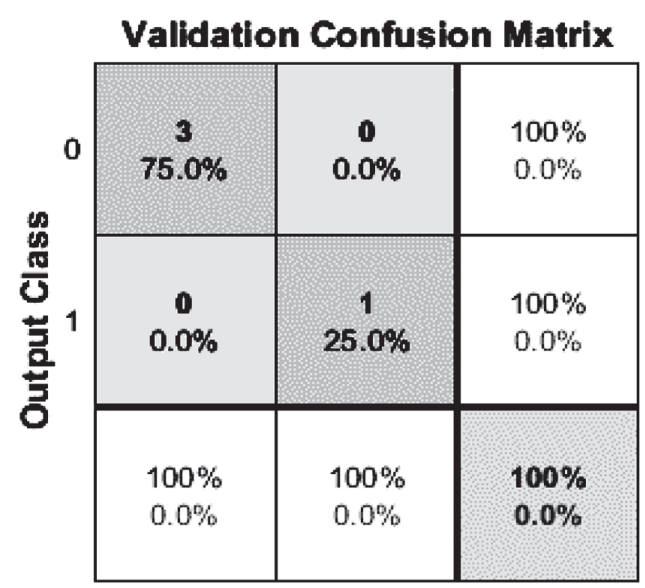

0

Target Class

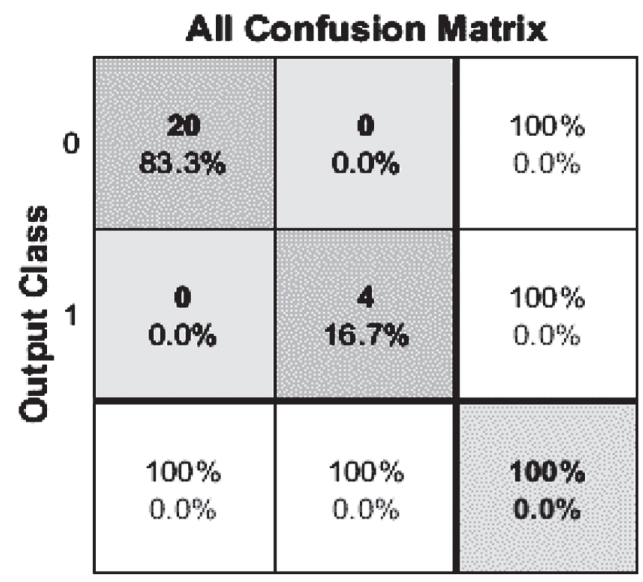

$\circ$

Target Class

Gambar 10 Matriks klasifikasi jaringan. 
sehat. Analisis terhadap citra dalam bentuk grafik nilai reflektansi menunjukan bahwa pemotretan pada ketinggian $50 \mathrm{~m}$ mampu membedakan antara tanaman sehat dan tanaman yang sakit pada batas nilai reflektasi NIR 45\%, dimana tanaman sakit memiliki nilai reflektasi NIR kurang dari $45 \%$. Berdasarkan hasil analisis nilai NDVI diperoleh akurasi $87.5 \%$, sedangkan metode terbaik dihasilkan dari hasil analisis menggunakan JST. Berdasarkan hasil analisis JST dengan menggunakan data 10 tanaman sehat dan 2 tanaman sakit pada ketinggian 50 m, 60 m dengan akurasi training jaringan $100 \%$ dengan 24 data, serta akurasi validasi data $100 \%$. Pada ketinggian $70 \mathrm{~m}$, nilai reflektansi spektral yang diberikan tanaman kelapa sawit tidak akurat karena pengaruh noise yang terlalu banyak dan sinyal yang ditangkap kamera multispektral semakin kecil.

\section{Daftar Pustaka}

Arifin, D., A.S. Idris and G. Singh. 2000. Status of Ganoderma in oil palm. Di dalam: Flood J,Bridge PD, Holderners M. (Editor), Ganoderma Disease of Perenial Crops. CABI Publishing, Wallingford, UK. hlm 49-68.

[BPS] Badan Pusat Statistik Indonesia. 2018. Analisa Komoditi Ekspor. Jakarta (ID) : BPS Indonesia.

Chipman, J.W., R.W. Kiefer and T.M. Lillesand. 2011. Remote Sensing and Image Interpretation 6th ed. New York (USA) : Willey.
Kasih, L.S.B. 2012. Penentuan iluminansi dan ketinggian terbang pesawat yang optimum untuk pemetaan tingkat warna daun padi [skripsi]. Bogor (ID) :Institut Pertanian Bogor

Liaghat, S., R. Ehsani, S. Mansor and H. Shafri. 2014. Early detection of basal stem rot disease (Ganoderma) in oil palms based on hyperspectral reflectance data using pattern recognition algorithms. International Journal of Remote Sensing, 35:10, 3427-3439.

Martawijaya, A., I. Kartasujana, K. Kadir, Y. Mandang, and S. Prawira. 2005. Atlas Kayu Indonesia Jilid I. Bogor. Badan Penelitian dan Pengembangan Kehutanan.Paterson RRM .2007. Ganoderma disease of oil palm: A white rot perspective necessary for integrated control. Crop Protect 26: 1369-1376.

Semangun, H. 2000. Penyakit-Penyakit Tanaman Perkebunan di Indonesia. Gadjah Mada University Press. Yogyakarta. 150-161.

Shafri, H., M. Anuar, I. Seman and N. Noor. 2011. Spectral discrimination of healthy and Ganoderma infected oil palms from hyperspectral data. International Journal of Remote Sensing, $32: 22,7111-7129$

Susanto, A. 2013. Laju Infeksi Ganoderma pada Empat Kelas Struktur Tanah. J Fitopanol Indonesia. 9(2):39-46.

Thomson, S.J., H.J. Brand and K.N. Reddy. 2016. Development of low altitude Remote sensing systems for crop production management. Int J Agric \& Biol Eng; 9(4): 1-11. 